\title{
COHESION IN FOREIGN LANGUAGE WRITING
}

\author{
Nyak Mutia Ismail \\ Syiah Kuala University \\ nyakmutiaismail2010@gmail.com \\ Lisma Linda \\ Iskandar Muda University \\ lisma.linda90@gmail.com
}

\begin{abstract}
I $t$ is important to keep the cohesion and coherence when writing; this is where the use of cohesive devices starts to be taken into account. This study sought the types of cohesive devices used by undergraduate students in their writing. The qualitative discourse analysis was used as the design of this research. The data were collected from seven undergraduate students as the respondents who were in the 6th semester at a private university in Aceh. These respondents were asked to write a descriptive text approximately 200 words in length and they were given forty-five minutes to finish their writing. The result unveiled that the type of cohesion devices which was majorly used was addition, as there are $94 \%$ of the additive device usage. Then, $75 \%$ refers to the use of cohesive devices as comparison, $56 \%$ as consequential, and $40 \%$ as temporal device. In can be concluded that the students use more addition in writing. As a suggestion, it is essential to shed light on their ability to employ cohesive devices more on other types in balance as it is necessary in contrasting, comparing, sequencing, giving exception, and illustrating.
\end{abstract}

Keywords: cohesion, cohesive devices, EFL writing, academic writing, ELT process.

\section{A. INTRODUCTION}

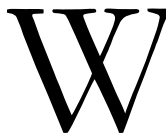

riting is one of the skill which assist language learners to be command in foreign language, belonged to reading, speaking and listening as well. Writing has been introduced since several centuries ago and developed significantly in some countries, particularly in Indonesia. It is different from speaking in regards of formality and complexity (Weigle, 2002). Writing is exceedingly complex skill in learning due to paying attention on some aspects of writing itself. Bell and Burnaby (1984, cited in Nunan, 1989, p. 36) states:

"Writing is an extremely complex cognitive activity in which the writer is required to demonstrate control of content, format, sentence structure, vocabulary, punctuation, spelling and letter formation. Beyond the sentence, the writer must be able to structure and integrate information into cohesive and coherent paragraphs and texts".

Measuring pupils writing ability is not easy; however, cohesive becomes one of elements which should be examined to compose an adequate piece of writing.According to Halliday and Hasan (1976) cohesion is a part of language system which exists in semantic part to clear up a meaning of the text. Cohesion belongs to discourse analysis text which link one word to another word to interpret the meaning of the text; one ties another to sum up the discourse within the text. A text is a unit of language and semantic relating to unified words that should 
differ from the grammatical units. A text sometimes considered as a huge-sentence, somehow, the grammatical unit is larger than a sentence; therefore, still related to the sentence. A good quality of the writing depends on a text; the words selected by the learners. The better they create the word coherence, the better they will gain the best writing proficiency. Indeed, enhancing the students' writing skill has long been a challenge.

This paper settled an objective to answer the following research question: what are the most common cohesive devices used by university students while writing English composition? This study is expected to fill in the theoretical gap that exists in the discipline of English writing and composition; while practically, it hopefully can be one of the references for other researchers who are interested in this discipline and for English teachers who are still struggling teaching writing to their students.

\section{B. LITERATURE REVIEW}

To examine the quality of writing level, Halliday and Hasan $(1976,1985)$, mentioned five cohesive relations which connects the unity of the text, there are: reference, substitution, ellipsis, lexical cohesion, and conjunction.

Reference is specific information which linked one word to another word. It divided into three types; pronoun (I, she, you, us, her, who, etc.), demonstrative (this, these, that, those, here, there, etc.), and comparative (such as, like, similar, in contrast, more, most, etc.). For example, I saw a woman in the pharmacy. She bought some medicines. Pronoun 'she' in the second sentence replaces the word 'a woman' in the first sentence. Additionally, Halliday and Hasan (1976) mentionedsix retrieval systems of reference, they are: anaphora, cataphora, exophora, homophora, endophora, and esphora. (1) Anaphora refers to the previous participant. For instance, Mary bought a new novel. Then, she presented it to Hendry. Pronoun 'she' refers to previous subject 'Mary' and pronoun 'it' deals with the object 'a new novel'. (2) Cataphora relate to the following participants. For example, when she was in senior high school, Rossa won a lot of championship. Subject 'Rossa' is related to the pronoun 'She' in the first sentence. (3) Exophora refers to the elements outside of the text or specifically in the context of situation. Have you bought the pen for me? The word 'you, pen, me' are attainable in this sentence because your speaking partner understand the context of situation. (4) Homophora refers to elements outside of the text in the context of specific sense or lexical such as naming head of the country which called president or the only thing in the world which recognized by the entire creature. For example, The sun is smiling in a whole day. Reference 
'the' in the sentence are retrieval from the context of speaker tenor which deals with the 'only sun of the earth'. (5) Endophora is reference an expression with another expression within the text. For example, I saw Ranti last night. She went to book store with her young brother. Pronoun 'She' refers to the word 'Ranti' which is written in the text.(6) Esphora refers to the participant in the same clause, such as: The girl who is standing of there is my sister-in-law.

Then, Substitution is the replacement of a word, phrase, or a whole clause by another in order to avoid repetition word. There are three kinds of substitution; nominal substitution (one, ones, same), verbal substitution (do, did or other auxiliary verb), and clausal substitution (so, not). For instance: I have two new clothes. One is yellow and another one is blue. The word 'one' is to replace the word 'clothes' in the first sentence due to omitting the same word.

Afterward, Ellipsis replaces the word by nothing or omitting language unit to eliminate the repetition lexical. There are three kinds of ellipsis; nominal ellipsis, verbal ellipsis, and clausal ellipsis. For example, she can drive the car but I cannot. The word 'cannot' is written to omit the same verb 'drive'. Even it is omitted but the sentence still understandable. Example of clausal ellipsis is; who was playing the guitar? Maya was. Even the writer does not write the word 'playing' for the second times, the reader could guess the ensuing lexical.

Moreover, lexical cohesion related to the meaning of the text. Halliday and Hasan (1976) divided types of lexical cohesion into reiteration and collocation. Firstly, lexical cohesion of reiteration separated into: (1) The same word. Example: Melly bought a new bike. The bike is black color. The second sentence repeats the same word which is 'bike', (2) Synonymy or near-synonym. Example: The teacher asked the students to write an article. The pupils should submit the article next meeting. The word 'students' and 'pupils' have the same meaning which called synonym,(3) Superordinate. Example: I bought a new Honda which is the best brand of motorycle. Here 'Honda' refers back to the word 'motorcycle'. Motorcycle is a superordinate of Honda. (4) General word. Example: A small thing could be big if you do a big effort. The word 'thing' is a general word which commonly used in cohesive term. Then, collocation is utilizing word used to associate the word become cohesive. Example: The doctor checked a patient and gave some advises for her. The collocation happens between 'doctor' and 'patient' which make the sentence coherence.

Finally, conjunction uses in paragraph writing to create explicit connection between sentences in order to produce coherence writing. Halliday and Hasan (1976) breaks down four types of conjunction: additive, adversative, causal, and temporal. Here some typical conjuctive word: 
Table 1. Types of cohesive devices

\begin{tabular}{|c|c|c|c|c|}
\hline TYPES & $\begin{array}{c}\text { DISTINCTIV } \\
\mathrm{E} \\
\text { INTERNAL }\end{array}$ & $\begin{array}{c}\text { EXTERNAL/INTERN } \\
\text { AL } \\
\text { COHESIVE }\end{array}$ & $\begin{array}{c}\text { PARATACTI } \\
\text { C }\end{array}$ & $\begin{array}{c}\text { HYPOTACTI } \\
\text { C }\end{array}$ \\
\hline Additive & $\begin{array}{l}\text { Moreover } \\
\text { In addition } \\
\text { Alternatively }\end{array}$ & $\begin{array}{l}\text { And } \\
\text { Or }\end{array}$ & $\begin{array}{l}\text { And } \\
\text { Or }\end{array}$ & $\begin{array}{l}\text { Besides } \\
\text { If not...then }\end{array}$ \\
\hline $\begin{array}{l}\text { Comparativ } \\
\text { e }\end{array}$ & $\begin{array}{l}\text { Equally } \\
\text { That is } \\
\text { On the other } \\
\text { hand }\end{array}$ & $\begin{array}{l}\text { Likewise } \\
\text { In contrast } \\
\text { Instead }\end{array}$ & $\begin{array}{l}\text { So } \\
\text { But }\end{array}$ & $\begin{array}{l}\text { like, as, as if, } \\
\text { like when, } \\
\text { whereas, } \\
\text { except that }\end{array}$ \\
\hline Temporal & $\begin{array}{l}\text { At the same } \\
\text { time } \\
\text { Finally } \\
\text { At first }\end{array}$ & $\begin{array}{l}\text { Meanwhile } \\
\text { Throughout } \\
\text { Previously } \\
\text { Thereupon }\end{array}$ & $\begin{array}{l}\text { And } \\
\text { Meanwhile } \\
\text { Then }\end{array}$ & $\begin{array}{l}\text { while, when, } \\
\text { as long as, } \\
\text { after, since, } \\
\text { now that }\end{array}$ \\
\hline $\begin{array}{l}\text { Consequenti } \\
\text { al }\end{array}$ & $\begin{array}{l}\text { To this end } \\
\text { Then } \\
\text { In conclusion } \\
\text { After all } \\
\text { Nevertheless } \\
\text { Admittedly } \\
\text { In this way }\end{array}$ & $\begin{array}{l}\text { To this end } \\
\text { Then } \\
\text { Otherwise } \\
\text { Therefore } \\
\text { For } \\
\text { However } \\
\text { Yet } \\
\text { Thus }\end{array}$ & $\begin{array}{l}\text { So } \\
\text { So } \\
\text { So } \\
\text { But } \\
\text { And thus }\end{array}$ & $\begin{array}{l}\text { so that, lest } \\
\text { so as, in case } \\
\text { if, even if, } \\
\text { unless } \\
\text { because, as, } \\
\text { since } \\
\text { although, in } \\
\text { spite of } \\
\text { by, thereby }\end{array}$ \\
\hline
\end{tabular}

Those are some conjunctive words that could cooperate in composing coherence paragraph. For instance, coffee gives some good effects for human. Besides, drinking coffee can cause insomnia. Here the connector 'beside' shows contrary idea between first sentence and second sentence.

Coherence paragraph writing consists of some good paragraph unity. Tsareva (2010) on her research Grammatical Cohesion in Argumentative Essays found that Norwegian and Russian learners utilized reference and conjunction most common to build cohesive relation between sentences and T-units whereas substitution and ellipsis are not portrayed extensively in argumentative essays. Tsareva (2010) stated that grammatical elements are often appearing in sequence sentence, yet they are not only figured out between two adjacent sentences but also between paragraphs. According to Tsareva final result, argumentative essay written by both of group does not have a significant distinction in cohesive items. The differences appear in the term of cohesive signal which has different types of cohesion; the link is not 
precisely dispensed in the paragraph. Norwegian and Russian used widely three element of anaphoric reference; personal, possessive, and demonstrative. Based on demonstrative reference examination, determiners work together with lexical cohesion. There are commonly showed that Russians learner essay was dominated by lexical cohesion.Additionally, both learners group utilized the article 'the' to speculate definite meaning in the text. Russian learners used the definite article to determine cohesive connection between sentences; however, Norwegian learners absolutely understand the use of the definite article. Some pupils still used the wrong article in writing English, and do not involve such the example on it.

Nevertheless, Kafes (2012) on his research 'Lexical Cohesion: An Issue only in the Foreign Language?' showed different result in examination of Turkeys's EFL learning to conduct cohesive text in their first language along with foreign language and also investigated the similarities of lexical reiteration cohesive device both in Turkey's and English. In this case, the writer examine the research using sample of 40 students' participation and used written text of a story based on a set of pictures with eight episodes as a data collection. The finding has shown that types of lexical cohesion 'repetition' were used most common by the learners in both languages, accompanied by superordinate words, and synonym or near-synonym word utilized successively in Turkey's and English.

There are three previous studies that have been done concerning the cohesion that are presented in this current study. First, it is a study by Singchai \& Jaturapitakkul (2016). This investigation looks at what cohesive devices are utilized in students' account papers and which strong device is most as often as possible utilized in each sort among three gatherings of students. Thirty participants, every one of whom were review 11 students at a government funded school in Bangkok, were isolated into three gatherings: propelled, moderate and apprentice. The principle instrument for information investigation was an example of 30 wrapped up student's story articles in which attachment was removed. The discoveries uncovered that four sorts of attachment: reference, substitution, combination and lexical union were found in students' account articles, while curved attachment was discernibly missing. The correlation of each sub-classification among three target bunches demonstrated that 141 individual references ' $\mathrm{I}$ ' was the most much of the time utilized in the propelled gathering, trailed by 113 added substance conjunctions 'and' in the propelled gathering, 95 collocations in the progressed gathering and 18 ostensible substitutions 'one' in the apprentice amass separately. This examination could give helpful recommendations to the 
EFL composing classroom for not just students to enhance the utilization of union in their compositions however likewise for instructors to set up a pragmatic composition instructional method for the EFL students.

Second, it is a study by Kalajahi \& Abdullah (2015). The point of their study was to discover the connection between utilization of talk connectors and attachment of writing in the composing tests of Malaysian school understudies. Thirty examples from each instructive dimension were picked arbitrarily from the Malaysian Corpus of Understudies' Contentious Composition. In spite of the fact that the rubric checks for five parts, including content, association, vocabulary, dialect use and mechanics, so as to deliver to the reason for the examination just "association" marks were considered since it is an exclusive segment which measures union of an article. The dependability test result demonstrated that between rater unwavering quality was high. The investigations showed that there was an extremely feeble negative relationship, however unimportant, between composing quality and the recurrence of the utilization of the connectors in the composition of Malaysian ESL understudies. The discoveries of the examination will likewise be talked about in detail.

And finally, the last prior study mentioned in this research is a study by Gholami \& Alizadeh (2017). This examination planned to differentiate the recurrence and thickness of the utilization of various sorts of lexical union in presentation part of local English and Iranian connected phonetic research articles. Forty presentation parts of local English and Iranian connected semantic articles; twenty from each gathering were chosen. For contrastive examination, the SPSS programming was utilized. The outcomes uncovered a few likenesses and contrasts in the utilization of lexical union sub-types in presentation part of local English and Iranian connected semantic research articles as far as recurrence and thickness of usage of sub-kinds of lexical union. The measurable instrument of the t-test was utilized to decide regardless of whether there was a critical contrast among the lexical union gadgets in the two gatherings of local English and Iranian writings. In light of these discoveries, the recurrence of sub-sorts of lexical union was in local English writings, while the recurrence Iranian writings was. Both local English and Iranian writings displayed a general inclination in utilizing redundancy, general thing and gathering yet metonymy and antonym were the slightest utilized sub-classifications in Iranian writings. The outcomes demonstrated that there were measurably huge contrasts in the utilization of lexical ties in presentation part of local English and Iranian connected phonetic research articles. As to thickness of the writings, the 
examination showed that presentation part of local English connected phonetic articles was denser than their relating Iranian ones.

In brief, what is novel to this study is that it investigated the cohesion devise used by univeristy students in Aceh. The difference between this current study and the studies elaborated above is that it analyzed the students' writing cohesiveness in termn of descriptive writing, while the studies above did not.

\section{RESEARCH METHOD}

The method used in this study was qualitative design. Specifically, it employed discourse analysis which scrutinized closely the discourse-in this case, the writing-in-depth to find the types of cohesive devices utilized by the respondents. There were seven six-semester students of Islamic State University who were involed as the respondents in this study. The data collection process was carried out by instructing the respondents to write a 200 -word descriptive essay as they were given forty-five minutes. Then, the data analysis was done through three-steps analysis as suggested by Miles, Huberman, and Saldana (2013) which were data reduction, data display, and data verification.

\section{FINDING AND DISCUSSION}

The result of the cohesive device utillization by the respondents is provided in the table below.

Table 2. Cohesive device utilization in EFL writing

\begin{tabular}{|c|c|c|}
\hline No & Type of cohesive devices & Utilization (\%) \\
\hline 1 & Additive & 94 \\
\hline 2 & Comparative & 75 \\
\hline 3 & Temporal & 40 \\
\hline 4 & Consequential & 56 \\
\hline
\end{tabular}

From the table above, it can be seen that the most usage used in the respondents' writing is additive cohesion type which stands for the percentage of $94 \%$. Then it is followed by the type of comparative with the percentage of $75 \%$, later come the type of consequential and 
temporal cohesion, respectively for $56 \%$ and $40 \%$. The additive cohesion was generally employed since the respondents repeatedly wrote the conjunction of "moreover" and "and". Meanwhile, for the comparative cohesion, the respondents used the word "but" frequently. In the type of temporal and consequential, which are least frequent employed by the respondents in their writing, they used "then" for sequential type-but basically means "and", not any certain sequence_-and the word "when" for the temporal type.

Below, it is provided the examples of chunks that were used in the respondents' composition.

\section{Excerpt 1:}

My father is a hero. He have good responsible and nice. And he also go to works every morning. And in the office, he is teach chemical and sometimes physics. But he never have complains about the job and he like his job very much...

In the excerpt above, it is clearly seen that the writer used the word "and" overfrequently. Basically, these sentences can be composed into simpler sentence(s) with less conjunction employed. Though, the overused conjunction seems to disturb the meaning in some certain ways. As urged by Faradhibah \& Nur (2018) that the overuse of certain transition signals (cohesive devices) in a paragraph is a sign of a writer who needs to improve concerning to the rubric of transition signal in use.

Then, the next excerpt is again provided to see more examples of the cohesive device utilization as in the following.

\section{Excerpt 2:}

I have a pet and it is a cat. It is with long white tail. But, the body is not white all. But, it has three colours, white, black, and yellow. When it eats, it eats fish. And sometimes I give my food to it, too.

But I eat the fish first and then I give to my cat because I love my cat very much...

The writer of the excerpt above used the word "but" frequently. Apparently, he only tried to add more information by misusing the connector words. The first two of the word "but" simply means "and". Then, what also comes to the authors' observation is that what lies in the excerpt and maked it not cohesive. In this excerpt, beside the mistakenly put words, there are also disorganized ideas where it can be seen that the writer tried to rush all of his ideas so that they became recklessly put. Later, the underlined chunks proved that the writer had some difficulties in using the pronouns or arranging words into a sophisticated order so that it does not have to be repeated in precisely that way again. It can be simply put into an ellipsis. As proposed by Ghasemi (2013) that a student prefer to use a certain cohesive device more than 
other cohesive devices for numoerous reasons, one of them is because of lacking knowledge about the written discourse.

Finally, below is another excerpt of a respondent who used the connectors in a balance and decent orders.

Excerpt 3:

My father name is Zulkifli. He is a farmer. He live in a village in Medan. In the morning, he go to the field rice very early morning. He does not have breakfast in the morning. For lunch, my mother bring lunch for bim to the field rice. Sometimes when holiday, I and my younger brother also join my mother to bring the food for my father. So, we eat together and we fell happiness. And we go home almost magrib in the evening.

The excerpt above can be claimed as a good composition since it goes in a fluent way as we can see the connector transition such as in the morning, for lunch (which means in the afternoon), and in the evening. She also added the word "sometimes when holiday", which is basically pleonastic and it can be used without the word "sometimes", she presented a temporal usage of the cohesive device. On one hand, another issue might raise from the excerpt above. The composition is no longer a descriptive composition and it simply turns into a narrative. On the other hand, we can imply that seeing this excerpt with better syntactic structure, it has a decent usage and well-organized ideas. Briefly speaking, the third exerpt implies that grammatical knowledge profoundly has impacts on the idea organization, as well as with the cohesive device usage. This proposition is also supported by Hinkle (2008). that most non native learners have problems with cohesion because they could not maximize the use of grammatical and lexical function in the target language. In addition, Hyland (2003) also sees that teaching the writing cycle to students is worth recommended.

\section{E. CONSLUCION AND SUGGESTION}

The conclusion that can be drawn from the result above is that more cohesive devices on adding purpose were used by the respondents. it was followed by comparing, then sequential, and finally followed by temporal. The use of additive devices is a very simple and staple use of a cohesive device which can indicates that the writer is still in the novice level. A gentle suggestion might be noted that for university level students, especially in the senior year, it is essential to maximize their ability on employing balance cohesive devices more on all types since the devices are crucial in comparing and contrasting, and sequencing as well as temporal device usage. 


\section{REFERENCES}

Faradhibah, R. N., \& Nur, N. A. (2017). Analyzing students' difficulties in maintaining their coherence and Cohesion in writing process. Eternal, 3(2), 179-189.

Ghasemi, M. (2013). An Investigation into the Use of Cohesive Devices in Second Language Writings. Theory and Practice in Language Studies, 3(9), 1615-1623.

Gholami, H., \& Alizadeh, F. (2017). A Contrastive Study of Lexical Cohesion in Introduction in Research Articles: Native English and Iranian Applied Linguistics. Journal of Applied Linguistics and Language Research, 4(8), 307-316.

Halliday, M. A. K, \& Hasan, R. (1976). Cohesion in English. London: Longman.

Hinkle, E. (2008). Teaching grammar in writing classes. In E. Hinkle, \& S. Fotos (Eds.), New perspectives on grammar teaching in second language classrooms (pp. 150-198). New York: Routledge.

Hyland, K. (2003). Second language writing. Cambridge: Cambridge University Press.

Kafes, H. (2012). Lexical Cohesion: An Issue only in the Foreign Language? English Language Teaching Journal, 5(3), 83-94.

Kalajahi, S. A. R., \& Abdullah, A. N. (2015).Discourse Connectors and Cohesion in Writing. Mediterranean Journal of Social Sciences, 6(3), 441-447.

Miles, M. B., Huberman, A. M., \& Saldana, J. (2013). Qualitative data analysis. London: SAGE publications.

Nunan, D. (1989). Designing tasks for the communicative classroom. Cambridge: Cambridge University Press.

Singchai, P., \& Jaturapitakkul, N. (2016). Cohesion in narrtive essay writing of EFL secondary students in Thailand. The New English Teacher, 10(2), 89-111.

Tsareva, A. (2010). Grammatical Cohesion in Argumentative Essays by Norwegian and Russian Learners. Unpublished master's thesis. The University of Oslo, Oslo. Retrieved from: https://www.duo.uio.no/handle/10852/26174

Weigle, S. C. (2002). Assessing writing. Cambridge: Cambridge University Press. 